\title{
HISTORICAL DISSERTATIONS DEFENDED IN 2007
}

Robertas Jurgaitis (Vytautas Magnus University, Lithuanian Institute of History), Vilniaus seimelio veikla 1717-1795 m. [Work of the Vilnius Dietine during 1717-1795]

The aim of the dissertation is to describe the specific characteristics of the work of the Vilnius Dietine: aspects of its functioning and organization, competence limits, ties with central institutions of the Polish-Lithuanian Commonwealth and state institutions of the Grand Duchy of Lithuania.

Individual sections analyze the following issues: the key laws regulating the activities of dietines in the Grand Duchy of Lithuania; the significance of the Vilnius Dietine, the seat of the institution, the convocation of dietine sessions and their duration, various aspects of its work; activities of envoys of Vilnius dietines at the Sejm sessions of the Commonwealth; their composition in terms of the elected deputies and work at the Supreme and Spiritual Tribunals of the Grand Duchy of Lithuania. Addenda contain material concerning frequency of the Vilnius dietine document entries in Vilnius castle and land court books in the period in question. In addition, a chronological list of Vilnius dietines, lists of elected deputies and envoys are provided.

Indrè Karčiauskaitė (Vytautas Magnus University, Lithuanian Institute of History), Katalikiškoji moteru judejimo srove Lietuvoje (1907-1940) [The Catholic Women's Movement in Lithuania (1907-1940)]

The dissertation analyzes one organization, namely the Lithuanian Catholic Women's Society. This is presented in the ideological context with an attempt to clarify why this particular conservative and ultra-Catholic organization involved ordinary women in a broader social life, thus expanding the network of civic society in Lithuania.

Four sections of the study present the context for emerging feminism and social Catholicism in Europe; these discuss activities of the Society during various periods; analyze the public discourse on the subjects of the woman's rights and duties concept in the family, professional and social life; discuss the practical work of the Society: expansion, activities of its branches, palpable efforts to improve education of women and social activities of the Lithuanian Catholic Women's Society. 
Arvydas Mikalauskas (Vytautas Magnus University, Lithuanian Institute of History), Valstybès tarnautojai ir valstybès tarnyba pirmojoje Lietuvos Respublikoje (1918-1940 m.) [Civil Service and Civil Servants in the First Republic of Lithuania (1918-1940)]

The aim of the dissertation is to scrutinize the organization of the civil service of the Republic of Lithuania in the period in question and reveal the progress of its development as well as socio-demographic and professional characteristics of civil servants.

The study is specifically oriented only to one part of the bureaucratic apparatus, i.e. its staff. It analyzes legal regulation of civil service and the main features of civil service organization. The focus is on aspects of politicization of civil service which were easily developed due to a linear management model, lack of legal acts regulating civil service and absence of the administrative court institution. The analysis of the key specific characteristics of civil servants and activities of their trade unions revealed that the rate of rising qualification of the personnel of the administrative apparatus was higher than the rate of changes in laws regulating civil service, and the professional movement among civil servants was active only in the first decade of Lithuania as an independent state.

Jonas Švilpa (Vytautas Magnus University, Lithuanian Institute of History), Kominternas ir komunistinis pogrindis Lietuvoje XX a. 4-ajame dešimtmetyje (organizaciniai veiklos aspektai) [The Comintern and the Communist Underground in Lithuania in the 1930s (Organisational Peculiarities of Activity)]

The dissertation is intended to view from within the existence and activities of the Comintern and the Lithuanian Communist (Bolshevik) Party at a given period, to follow up changes occurring in those organizations within the context of dynamic conditions.

The first section covering the period of 1928-1935 is focused on the process of leadership centralization in the Comintern and the power struggle within the LC(B)P) for the leadership position. The second section (1935-1938) discloses a systemic shutdown of the Comintern, as well as $\mathrm{LC}(\mathrm{B}) \mathrm{P})$ work. The third section attempts to review activities of the $\mathrm{LC}(\mathrm{B}) \mathrm{P}$ ) when the reconnaissance institutions of the SSSR using the Communist parties of the Comintern as a cover were actually engaged in spying missions. The last section of the study deals with the problematic period of 1938-1939 when the relations between the Comintern and the LC(B)P) developed in a highly varied manner: they were either completely terminated or newly resumed. 
Ingrida Jakubavičienè (Vilnius University), Lietuvos vokiečiu nacionalsocialistinè veikla (XX a. 3-4 dešimtmečiuose) [National Socialist Activities of Lithuanian Germans (in the 1920s-1930s)]

The analysis of national socialist activities undertaken by Lithuanian Germans has indicated that in 1925-1928, when individual residents of the Klaipeda Region made first contacts with the centre of German NSDAP in East Prussia, the first secret groups of national socialists were established with the membership of a few hundreds. In June 1933 Nazi parties led by T. Sass and E. Neumann were established in the Klaipeda Region (with the blessing of the German NSDAP) and Nazi activities were included into the already functioning Kulturverband of the German Lithuanians. The Reich directly included the said German organizations in pursuing its interests: the Kulturverband of the Lithuanian Germans participated in helping Germans and Nazis in the Klaipeda Region to transfer the Region to Germany. Therefore, their activities were continuously supervised by agents delegated from the centre of the German NSDAP as well as the General Consulate of Germany in Klaipeda and the Legation in Kaunas.

The financial support of Germany was particularly necessary for activities of national socialists and accounted for 4 million Reich marks each year. Due to such financing the German youth, sports, religious organizations as well as educational and cultural institutions functioning in Lithuania were closely related to Nazi organizations.

Simonas Strelcovas (Vytautas Magnus University, Lithuanian Institute of History), Antrojo pasaulinio karo pabégéliai Lietuvoje 1939-1940 metais [The World War II Refugees in Lithuania in 1939-1940]

The dissertation attempts to reveal the circumstances of war refugees in Lithuania, their relationship with local residents, representatives of the local administration and international organizations.

The first part discusses similarities and differences in concepts of aliens and war refugees with regard to Lithuanian legislation. The second part of the study analyzes issues related to interned Polish soldiers: the internment process, the creation, development and liquidation of the network of camps. The third part focuses on civil refugees, mainly Poles and Jews: their legal and social status, relations with local residents and representatives of such organizations as the Commissariat for War Refugees Affairs and the Lithuanian Red Cross. 
Saulius Grybkauskas (Vytautas Magnus University, Lithuanian Institute of History) Pramones valdymas sovietineje Lietuvoje 1965-1985 m.: itampos ir konfliktai [Industrial Management in Soviet Lithuania in 1965-1985: Tensions and Conflicts]

This dissertation attempts to define the system of industrial management in Soviet Lithuania, its conflicts, expression of systemic tensions and clashes.

The four sections of the study analyze the following issues: changes in the Brezhnev period, functions of governing institutions, importance of informal contacts for industrial management, the economic nationalism of the Lithuanian nomenclature; the concept of republican economic interests as perceived by the LSSR authorities, conflicts between local authorities and union-level ministries; relationships of union-level enterprises with local and central authorities; conflicts in enterprises caused by the industrial management system: relative 'democracy', significance of the director's and engineers' authority in management, problems of the Soviet 'equality'. The data regarding KGB work at industrial enterprises, its tendencies and stages etc. are provided in tables. 